\title{
The Phoenix Rising: Widows Living Positively with HIV/AIDS
}

\author{
Sonny Jose ${ }^{1, *}$, Lakshmi Mohan ${ }^{2}$ \\ ${ }^{1}$ Loyola College of Social Sciences, Trivandrum 695017, Kerala, India \\ ${ }^{2}$ ASAP, Government of Kerala, Trivandrum 695001, Kerala, India \\ *Corresponding Author: sonny.jose@gmail.com
}

\begin{abstract}
HIV/AIDS continues to be a massive development challenge for humanity as it deprives families, communities and entire nations of their young and most productive people. The stigma and discrimination towards persons living with HIV/AIDS not only affect them, their families but also prevent them from accessing treatment that is very important for their survival. This has significant ramifications on women especially since they are always more than often innocent victim infected by their husbands who eventually die within months of their being diagnosed as HIV-positive. Women with HIV or AIDS are sometimes mistakenly perceived to be the main transmitters of sexually transmitted diseases (STDs). Generally women are at a greater risk of heterosexual transmission of HIV and biologically twice more likely to become infected through unprotected heterosexual intercourse than men; they are also often blamed by their parents and in-laws for infecting their husbands, or for not controlling their partners urges to have sex with other women. The present paper is a case study that explores the experiences of a persons infected with HIV/AIDS, with their immediate family members, healthcare system, work place and religion and other social and institutional domains. It also takes note on the response of the affected HIV positive widows to their own infection. An attempt is made by the researcher to study and understand their lives and to document their strengths in adapting to their changed status and living positively with HIV/AIDS.
\end{abstract}

Keywords Feminisation, Discrimination, HIV/AIDS, PLHIVs, Stigma, Resilience, Widows

\section{Introduction}

HIV/AIDS is a massive development challenge of global proportions facing human societies. Of the 35 million people living with HIV/AIDS in the world, 19 million do not know they are HIV positive. Adolescent girls and innocent young women account for one in four new HIV infections in sub-Saharan Africa. The vulnerable especially, prisoners and women are much more susceptible to HIV, Tuberculosis and Hepatitis-B and Hepatitis-C than the general public. Too often people at higher risk of HIV infection face multiple issues (UNAIDS, 2014).

In the beginning, AIDS was described as a disease complex in homosexual men and resulting from '... a virus called HIV, which spreads from person to person through body fluids' (Starkie, J. \& Dale, R., 1988: 9). This labelling has created stigma among persons living with HIV/AIDS forcing them to bear the brunt for in most cases for no cause of their own. HIV/AIDS has been identified by the mainstream society as a behaviour-related disease that "affects others", although the disease is no longer restricted to groups that have been traditionally marginalized. The psychological reactions in society stubbornly remain resistant to accepting the reality.

Since HIV hits active young adults, it could be described as 'the killer of the fittest'. The population it leaves behind, is less able to cope; in other words the world keeps losing its most productive sector. Louwenson and Whiteside have summarised the devastating implications of HIV/AIDS as unique because it deprives families, communities and entire nations of their young and most productive people.

At different levels it can affect the individual as well as society; it can affect the individual psychologically, physically and socially. The impact of the disease on a society can be economic, demographic and social. The impact of the HIV/AIDS epidemic on both national development and household economies has compounded a whole range of challenges surrounding poverty and inequality. The epidemic is deepening poverty, reversing human development achievements, worsening gender inequalities, eroding the ability of governments to maintain essential services, reducing labour productivity and supply, and putting a brake on economic growth. The worsening conditions in turn put people and households even more at risk of, or vulnerable to, the epidemic, and sabotages global and national efforts to improve access to treatment and care (UNDP, 2005). A deeper understanding needs to be evolved to break this vicious cycle and to ensure a sustainable solution to the HIV/AIDS crisis. 
In 2009, it was estimated that there were 2.4 million people living with HIV/AIDS (PLHIVs) in India, equating to $0.3 \%$ in prevalence. While this may apparently seem low because India's population is so large, it stands third in the world, in terms of greatest number of PLHIVs. With a population of around a billion, a mere $0.1 \%$ increase in HIV prevalence would increase the estimated number of people living with HIV by over half a million. HIV infection in India is currently concentrated among poor, marginalized groups, including commercial sex workers, truck drivers, and migrant labourers, men who have sex with men (MSM) and injecting drug users (IDUs). Transmission of HIV within and from these groups drives the epidemic, but the infection is spreading rapidly to the general community. The large population, low literacy and even lower levels of awareness has made AIDS one of the most challenging public health problems ever faced by the country. As it's a life-threatening disease, people react to it in strong ways. HIV infection is often associated with behaviour's (such as homosexuality, drug addiction, prostitution or promiscuity) that are already stigmatized in many societies. India is painfully realizing the impossibility of achieving the dream of 'Health for all' in the foreseeable future.

\section{Feminisation of the HIV/AIDS Pandemic}

Rarely perceived as a major public health issue in India, AIDS has taken on nightmarish proportions in recent years. Globally, by the end of 2005, an estimated 40.3 million people were living with HIV, and of these, as many as 17.5 million (i.e. more than 40 percent) were women. This bridge population, mainly migrants and truckers, extend the transmission to their female sexual partner(s) and from them to their children. Preventive interventions focused on high risk groups have attained impressive results reducing the incidence of HIV. However, new data are suggesting that the HIV epidemic in India is evolving into a more generalized distribution in the population.

Though the "feminisation" of the pandemic is more apparent in Saharan Africa, the HIV infection rate among women, in India, is also steadily rising. In India, women account for around 2 million of the approximately 5.2 million estimated cases of people living with HIV in 2005 , constituting 39 percent of all HIV infections. Of the 1,11,608 cases of AIDS detected in the country till 31 July 2005, females accounted for almost 30 percent. It has been found that the impact of HIV/AIDS reaches far beyond the health sector, with severe economic and social consequences. The impact is much more severe on women than on men. Women and girls seem to bear the brunt of the pandemic in many ways and the disease disproportionately affects them psychologically, socially and economically.The epidemic continues to shift towards women and young people with about $25 \%$ of all HIV infections occurring in women. This also adds to mother to child HIV transmission (MTCT).The predominant mode of HIV transmission is through heterosexual contact. Even within the same country, responses to HIV/AIDS will vary between individuals and groups of people. Religion, gender, sexuality, age and levels of AIDS education can all affect how somebody feels about HIV and AIDS. Discrimination, Stigmatization and Denial (DSD) are the expected outcomes of such values, affecting life in families, communities, workplaces, schools and health care settings. Because of HIV/AIDS related DSD, appropriate policies and models of good practice remain underdeveloped. People living with HIV and AIDS continue to be burdened by poor care and inadequate services, whilst those with the power to help, do little to better the suffering.

Women with HIV or AIDS may be treated very differently from men in some societies where they are economically, culturally and socially disadvantaged. They are sometimes mistakenly perceived to be the main transmitters of sexually transmitted diseases (STDs). Men are more likely than women to be 'excused' for the misdemeanuors that resulted in their infection. Generally women are at a greater risk of heterosexual transmission of HIV. Biologically women are twice more likely to become infected with HIV through unprotected heterosexual intercourse than men. In many countries women are less likely to be able to negotiate condom use and are more likely to be subjected to non-consensual sex. Women are also often blamed by their parents and in-laws for infecting their husbands, or for not controlling their partners urges to have sex with other women. The rising number of women (over 1.9 million at the last count) afflicted with AIDS is setting off alarm bells in the in the Indian medical fraternity - especially since more than 90 percent of these are married women and are in a monogamous relationship.

Female widowhood has been recognized as one of the most important risk factors for HIV infection in India in at least two previous population-based studies. The most important route of HIV transmission in India is through sexual contacts and more than $90 \%$ of infected women acquire the infection from their husbands. It has been observed that HIV is an important cause of death among young men in Indian States with higher prevalence of HIV. Since husbands acquire HIV earlier, they are likely to die before their wives, even if both members of the couple are infected. In many cases, these HIV positive widows are left in deplorable situations due to illiteracy and lack of emotional and economical support. Specific programs focused on HIV screening and providing economical and psychological support of HIV positive widows are urgently needed in India.

Today, in many countries, women are mobilized in the fight against AIDS, but their concerns continue to receive little attention (Kmietowicz, 2004). Women are underrepresented, and are sometimes noticeably absent from, the international forums where AIDS policies are decided and funds are allocated. (UNAIDS, 2006) Rather than accepting victimhood, how women act and accomplish change has become central to contemporary discussions on 
women's empowerment and choice. This present paper is a case study that explores and documents the experiences of a person infected with HIV/AIDS with their immediate family members, healthcare system, work place and religion and other social and institutional domains. It also take a note on the response of the affected HIV positive widows to their own infection.On this basis an attempt is made by the researcher to study and understand their life and to document their strengths in adapting to their changed status and living positively with HIV/AIDS.

\section{Statement of the Problem}

At the end of 2010 it was estimated that out of the 34 million adults worldwide those living with HIV and AIDS, half are women. The AIDS epidemic has had a unique impact on women, which has been exacerbated given their passive role within developing societies and their biological vulnerability to HIV infection. Women PLHIVs may be treated very differently from men especially in developing societies and theocracies, where they are socially, culturally and economically disadvantaged. Especially HIV-positive widows face a double jeopardy both as a widow and an HIV positive. They suffer the dual burden of self-stigma as also discrimination from the family and society.

Kerala, is a state in South India that records the highest literacy rate among both men and women. But high literacy rates alone do not necessarily translate it into high social status or empowerment. In India, as elsewhere in the developing countries, AIDS is perceived as a disease of "others" - of people living on the margins of society, whose lifestyles are considered 'perverted' and 'sinful'.The enigmatic life of HIV infected widows and the voyeuristic explorations by the media into it is symbol of this stigma. Though Central and State governments and NGOs have made sincere efforts to protect HIV/AIDS patients, there seems a lot still needs to be done in terms of raising the quality of life of infected widows, creating an environment with new expectations of life and maintain equality with others. The present paper ventures to explore, understand and document the life experiences, challenges encountered by widows who are PLHIVs, and their subsequent learning and adaptation to their untenable status.

\section{The Methodology}

The study being exploratory in nature, required in-depth interviewing to understand the distinct complexity of each participant. The study requiring the best use of idiographic case study (Breakwell, Hammond, and Fife-Schaw, 2000) pursued the multiple case study design. Three widows who were PLHIV were interviewed. The objectives of the paper were as listed below:

1. To assess the quality of life of the PLHIV widows

2. To understand the coping strategies adopted by the PLHIV widows

3. To understand the various social support systems moderating their adjustment

4. To document the better practices adopted in coping with the challenges

The three PLHIV widows interviewed for the study were beneficiaries of the Kerala State AIDS Control Society's intervention, and happened to be bread winners of families with at least three dependents; these widows had survived HIV for more than 10 years after infection. All of them had a minimum of secondary education. Data was gathered from all the three cases on an ethnographic mode over a period of six months.

\section{Theoretical Frameworks}

This being a qualitative invocation of lives of widows who are PLHIV, requires theoretical exploration of stigma and how these individual widows cope and get beyond these at the same time passing through various grieves - the loss of the spouse (widowhood), living through the trauma of discovering their HIV Positive status and finally coming to terms with it. Theoretical frameworks referred to include Erving Goffman's theory of social stigma, in which stigma is an attribute, behaviour, or reputation which is socially discrediting, causing the affected individual to be mentally classified by others in an undesirable, rejected stereotype, rather than in an accepted, normal one. The paper also makes use of the Five Stages of Grief - Denial, Anger, Bargaining, Depression and Acceptance, first introduced by Elisabeth Kübler-Ross, and popularly known by the acronym DABDA. This explains the various stages an individual goes through while coping with a crisis, whether it be an accident, injury, bereavement or terminal illness. This is further qualified by Extended Grief Cycle shown in the chart below, indicating the roller-coaster ride of activity and passivity a person undergoes in a crisis or trauma in their desperate efforts to avoid (maladapt) the impeding change. The transition ultimately ends in acceptance of change leading to adaptation. 


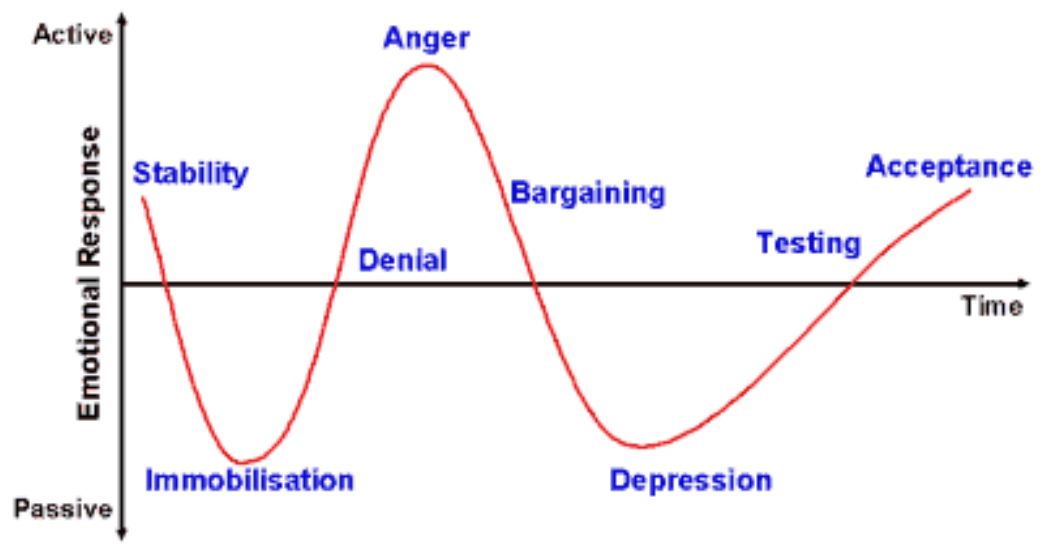

\section{Data Analysis}

Data analysis was done by way of descriptive comparison, i.e., describing and perhaps also explaining the invariances of the objects on the basis of the conceptual and suitable theoretical frameworks. The researcher attempted to understand about the scope of positive living by assessing the quality of life of PLHIV widows, various scoping strategies adopted, the various social support systems and documenting their coping strategies. The various consideration for positive living included: plans for the future; strategies to gain emotional support; avoidance of unhealthy practices (tobacco, drugs and alcohol); eating healthy and keeping hygiene; routine exercise and sleep; avoidance of other infections; general health monitoring; spirituality and other counseling; living responsibly to prevent transmission of infections to others; and active engagement with the community and society at large.

\section{Case: Agipa}

Agipa, at the time of the study was 35 years old mother of two lovely girl children. She was $163 \mathrm{cms}$ tall, well-built and wheatish in complexion. She hailed from an orthodox Hindu, Nair family, and stayed with her parents and children in a modest, comfortable mansion. She happens to be the only bread winner of the family. She wore simple, yet impeccable dresses. She always bore a warm and affectionate smile and was most willing to engage in friendly talk, making her very popular among her colleagues. During a visit to her workplace, the researcher found her colleagues, both seniors and juniors crowding her cabin eager to share their tiffins.

She started off her narration philosophically stating, “...you don't need to have a disease to see it as a problem in life... as human beings we already have had enough and more problems in our lives to worry about. ...people contemplate of suicides and ending their life even for small reasons. Looking back at my life, I too have contemplated suicide; and yes!, it would have been an easier choice. But,
I had to gather strength to tide over the crisis because I had people depending on me." She was more than willing to share her life story, if it could have been in any way an inspiration for others.

\section{Life till Marriage}

Her childhood memory goes back when she was in $6^{\text {th }}$ standard. Her father was a peon in a private firm, while her mother was a house wife. She had an elder brother, three years elder to her. They were staying in her father's inherited house along with her paternal uncle and grandparents, being part of a joint family. She attained puberty when she was in sixth standard vacation. She was a lover of sports and was very passionate about Hockey thanks to the encouragement of father's. She was educated in English medium school until $5^{\text {th }} \mathrm{Std}$, after which she migrated to a Government school owing to financial constraints. Her father worked two jobs at a private firm. Later, he lost one of the jobs, after being diagnosed with bipolar disorder. His mental illness took a turn for the worse with him unexpectedly turning violent, hurting others and himself during these bouts; he was forced to undergo ECT and hospitalisation at least for a fortnight twice or thrice a year. These incidents made her insecure because of he was once a great support to her; his mental sickness affected her self-esteem too. Her father eventually lost both his jobs, and their misfortunes compounded with her paternal uncle taking over their property forcing them to leave the house they stayed in,for a rented house. Her grandmother, who worked at a school for mentally challenged, found her mother work as an "Aaya"; this was a great respite.

AGIPA describes; "I lived seeing all these setbacks and feeling helpless. But I was a good student, always wanted to study and studied well. I went on to play Hockey at State, University and National levels." During this time she was on a lot of pressure to stop studies. She studied very hard and scored very high marks in her SSLC. This provided her the necessary confidence to enroll herself in a government college and pursue $2^{\text {nd }}$ Group (Biology). She supported her studies by taking tuitions and earned enough to pay the rent 
for their house. The family was managing quite well with her and her mother's income. Unlike her brother, family was a priority for her even at her childhood days. She was forced to discontinue studies as she was hospitalised with a bout of typhoid lasting 20 days during the final practical exams. Although her father wanted her to continue higher studies, her mother and relatives planned to marry her off. But then, her father had little say in the family matters, and moreover he had changed a lot and preferred to stay in his own cocoon.

In spite of all the pressures she got herself once again enrolled for the Pre-degree Commerce in a private college and completed the program by attending simultaneously the morning and day batches. She joined in for B.Com.in the same private college with her limited income. It was during this time her family started looking for marriage proposals. She like any other girl of that age wanted to have an affair or a relationship but she stopped herself because for her family. There was a boy who was genuinely interested in her since three years after she joined the college. She rejected his proposal fearing that the society will ostracise her given her father's mental illness which would be further complicated by marrying a man from the lower caste, adding up to her already burdened mother and family. She finally summed up saying, "I buried those feelings deep inside me and preferred an arranged marriage to make my parents happy".

\section{Marriage}

She went on to describe her expectations regarding a marriage.

"I had a lot of dreams about my marriage. Whenever I told my mother that I wanted to go for a movie, to the beach or on a picnic, she would tell me that we could not afford it. However, Admeasured that I could get to do all I dreamt of with than man I get married to, and that then, I would be happy. I grew up listening to these promises and really believed so."

She wanted to be her mother,someone always willing to take care of her father as well as the children, no matter what,. She wanted to love her husband so much and lead a happy life. Although her father wanted her to pursue her future studies and work, she was forced by her mother to marry against her wishes. Her mother was also so worried because of the family issues and their financial constraints that they overlooked other marriage proposals. As if by design her aunt's co-worker bought an alliance for her. She did not have a proper formal saree nor gold to wear even for "pennukanal chadangu" (the first visit by the bridegroom's family) and so borrowed the ornaments and dress from her intimate friends. She found him very handsome and adorable anybody and fell in love with him at first sight. The guy liked her too and was ready to marry her without any specific demands or dowry. Although her husband's parents insisted that he get married to a girl with an inheritance (immovable property), he insisted on following-up the alliance with AGIPA. Although, he wished to get married earlier, her family was not ready and requested a respite of about 10 months for the necessary arrangements for the marriage. So they had a betrothal a month later and she continued with her studies.

After this they used to meet quite often, and he behaved well too. Being was a taxi-driver he was hardly available. Her father worried that she was too educated for him. But all that did not really matter as she rated herself inferior because of her financial and family problems. Twice during those 10 months prior to marriage he was admitted to a hospital because of some infection. They got married in 1997 in spite of other more attractive proposals coming up even after the betrothal. She goes into a soliloquy: "I see all this as God's play... it is my fate to go through all this. Nobody ever had any doubt about him; only a friend of his knew about his infection, not even the doctors. Only after his death did his friend disclose that he was HIV positive".

\section{Life after Marriage and Sexual Life}

Her mother went through great hardship trying to raise money for her wedding; she borrowed money as they had no savings. Her family provided her 10 sovereigns of gold and her relatives pitched in with another seven as dowry. She also inherited 14 cents of land in Parasala. Her family got into a debt of 60,000 rupees because of her marriage. Her mother-in-law was very aged. She had nine children among whom, her husband was the youngest. The mother-in-law was nasty and was hell bent on getting Agipa to obey her as she did not approve of the wedding in the first place.

During the period following the engagement her biological mother had prepared her so well for the new life ahead. Being six years younger to him, she was advised by her mother a lot as it was her duty to keep the family together. Her husband being his mother's pet, and the one taking care of her, gave her the entire money he earned. This practice created issues in her marital life that lasted five years. The first year of her marital life was the most memorable in her entire marriage; but even then he drove extensively as was required by his job. She hardly had any quality time with him as he used to stay away for weeks and sometimes months. She remembers having to wait for her husband having prepared his favourite dish. About a month into the marriage she knew that he had habits of alcohol and smoking.

She took three months to get adjusted to sex life; but he was both "exciting and very demanding." She was ok with it as long as she thought he was keeping his limits. He usually behaved sensibly before taking alcohol; but after taking alcohol, he treated her like "a prostitute". He used to sexually abuse her, but she "tolerated all that". She was 
apprehensive as she had heard stories from her friends, then married. As days passed by their sexual encounters graduated from being gentle to "wild, hard-core sex". The respondent said it was "not always pleasurable" but "more of pain, and increasingly distasteful". Most of the time she gave in taking it for granted as being her duty; she dreaded it as she had to do it for him even while he was sick. Three months into their marriage, she contracted an infection and had to visit a clinic, where she was tested negative, while he was detected positive for VDRL (a test for any sexual infections). After this episode they started using condoms as a precaution, on his insistence. After a year's time she insisted her husband that they have regular intercourse to conceive as she found it awkward to go without a baby. Furthermore everybody around had begun asking when the baby was coming.

\section{Child Bearing and Delivery}

After a year and a half years she got pregnant. Being an alcoholic he also had a problem with his sperm count. When the researcher clarified whether not the VDRL test had hinted to her about his promiscuity and HIV status, Agipa claimed that she "was unaware". For that matter even the doctor did not bother to explain to her about the details; but strangely he enquired whether their marriage was a love marriage. As per the Hindu tradition, she relocated to her home during the seventh month of the pregnancy. Her husband presented stronger symptoms when her first baby was eight months old. . He was first diagnosed with herpes's sexually transmitted disease on his right shoulder. It was during that time that her mother asked for money; so they sold their landed property and gave her Rs. 60,000 to settle the debts. By this time he had changed a lot in his behaviour. He stared demanding and harassing her family and her for money as he started to build a house on his own plot.

She became pregnant for the 2nd time when her first daughter was two and half years old. This was not a planned pregnancy. When he gathered that she was pregnant for the second time, he wanted her to abort the child. Agipa was however decided as she faced difficulty during the first pregnancy, and thought it the right time to have a second child; she affirms "I thought it was God given,... and I wanted to have it". Her husband even threatened her with divorce. Five months into the second pregnancy, he started to misbehave always attributing faults to her and beating. He even attributed his physical discomforts and worsening situations to her. Next, he wanted her to leave him but she refused. He persistently got sick, and her mother-in-law blamed her for "not caring" or cooking him "good food" as a reason for his getting sick.

He then started harassing her for dowry and forced her to leave their house until she brought back more money. One day she was forcefully sent away from her husband's home. She remembers that at that moment she did not have even Rs.20 in hand. She felt terribly shaken inside being five months pregnant and having nowhere else to go with her two-year old baby. "I felt I neither had my family nor him to support me." She planned to go to a railway track and commit suicide. But when she was passing the temple she always used to visit, she felt "a force" stopping her from doing so. It made her think about her kids. She believes that it was easwaran (God) himself.

She gathered courage and went to her own house. She later requested her parents to arrange more money. Her mother managed to raise the money demanded for and handed him a cheque. Yet again, her husband would precipitate problems and demand ready cash. Her husband used to accuse her of "foul play" and beaten her up. Each time her mother dutifully sourced money and sent her back. Her husband continued to threaten divorcing her in the name of the children or the property. Having acceded to his demands, he could not come up with anything to throw her out. He had no other option but to retain her. She reasons that, "He was perhaps scared to reveal his status and was doing all this to conceal this. He was so desperate and tried all within his means to force me to leave him. But I stayed on because I loved him and I wanted the family to stay together." By that time their house was half complete, and his condition was worsening. He even tried siddha medicines for his skin issues. Yet he did not take it on time made things worse. It was his friend who took him to the hospital as he never wanted her to accompany him. Moreover, during that specific period she too was so unhealthy and had lot of domestic work - cooking, washing, as well as taking care of his family and children, especially the infant. "I was secretly praying and wishing deep inside that things were getting better though I had a lot of struggles". Soon her husband insisted that she severe all connections with home. He wanted her to live separately as soon as possible and stay away from all.

\section{Diagnosing with HIV}

Her memory about the testing for HIV for the first time goes back to the fateful day, her husband came home after being tested. She remembers seeing him unusually upset that day. He went to his room and started drinking. Later, he informed her that he was diagnosed with "skin cancer" and that he wanted her and the child to be tested as well. When her husband told first her this, she too went into denial. She thought "this can never be!". Her husband kept crying and mumbling "I have cheated you...you can't forgive me ... no one can! ...I have committed so many sins and even hurt you too". These words made her tensed and more worried. She recalls that she was seven months pregnant then. "I was disturbed and prayed it was never true". Next day his friend took her to hospital as told by her husband. She was told not to tell anyone were they were going. She was taken for her HIV testing, and there she met a counsellor, who showed a lot of sympathy towards her. There he started giving her pre-test counselling and asked did she know about the purpose of the visit, her life history and so on. From the 
conversation that ensued, the counsellor perhaps assessed her to be a woman with the tenacity to survive, and, the importance and centrality she accorded for life and family. Then he broke the bad news narrating how her husband had been diagnosed with AIDS and had very little time left. He informed her on the need to be tested as well. She went on to describe, "It was that moment in my life I felt entire world around closing on me...I was shattered, and could not accept it at all!". She remembers repeatedly asking "My husband have AIDS? ....My husband...? My husband? Does that mean he will he will die and I and my daughter alone have to live, alone? That just can't happen, can it?" She then remembers losing her senses and reacting violently.

Finally, after a lot of convincing she took the blood test. As she got out of the laboratory cubicle, she saw her husband waiting. She even remembers him not daring to even look at her. She remembers sitting at a table far away from him and his friend. She recalls, having sat before the counsellor refusing to shed tears. But when she sat there for some time, she just burst out in tears, not knowing how to control herself. At that time her husband too started weeping. When she realised that she could control herself, she claimed to be fine and mustered courage to tell them that she would "wait for the result". Fate had it, that she was tested HIV-positive, while her child was negative. Her first reaction was to ask about the baby that she was carrying. But then, they said that it had to wait until the baby was born as it could not be assessed then. Later, the counsellor asked her decision regarding her life and family. She responded saying she will stay with her husband as long her husband is alive. In her own word, "I had made a lot of sacrifices to live a life, and, I, now, cannot let go my life again nor leave my husband due to this infection now". She remembers accompanying her husband out of the Voluntary Testing Center (VCTC), going to the beach and ordering food. Yet, she could never eat it. She reflects, "My heart was like the tidal waves in the sea...never calm". After the dine, her husband took her to the sea and reminded that he would be dead within a few days, and that she would follow, and that their kids would have to survive alone. He pleaded with her to jump from this bridge with them, so that they would not have to wait for people to insult you". Agipa thought for a few minutes, but then gathered strength and resolved to be bold, ready to see what is in store for them.

The months that followed were extremely distressing. With each passing day he husband grew weaker, sick and bald. She did everything possible within her means to get him back to life. After having confirmed their HIV status, her husband wanted to leave his family and live with her parents, provided his status was not disclosed to her parents. They did return to her family. But what transpired next was more shocking. Back with her own family, she saw her mother was bedridden for three months following a spine injury. She felt guilty because she never knew of this; after all, she was following her husband's desire. Any hope of being taken care by her parents faded. She had to care for her mother from then on, while also looking after her weak husband. She on the other hand was growing weaker day by day, and had to visit doctors concerning her pregnancy. She remembers spending sleepless nights and starving most of the days until the penultimate month of her pregnancy. Wherever they went for pregnancy check-ups, her husband resisted her revealing their HIV status. When found HIV positive, they faced discrimination at the hospitals - private and government. Soon they were in no position to answer questions from relatives about reasons for frequently changing doctors.

At one point he even forced her to keep the status as secret and made her burn all the test results. However, she insisted in revealing her status to doctors so that they take the necessary precautions. She remembers an incident where the Government doctor inscribed the letters HIV and circled it in red on her medical prescription; she felt detested the callousness and whole process of check-ups, and decided never to go back to a hospital, but rather deliver the child at home. During this phase of life her husband started regretting his life and felt guilty about being unfaithful to his wife. He took to alcoholism. They were forced to stop the construction work of their house during this time. He, however, began to show remorse and confessed about his other sexual partners he had after the marriage. He even pleaded with her to leave him. Even after all this hurt and betrayal, she could never hate her husband; after all she loved, cared and shared her body only with him. This made him even more guilty and difficult to face her. After the seventh month of her pregnancy, he started caring for her, often overdoing things. But she was numb to it as she realised that there was no point, and the worst had already been done. She does not know even now whether her "happy-go-lucky" attitude hurt him; because he looked more embarrassed and became even weaker. She claims that until the day he died she never shouted at him nor showed any anger. Yet she shared with him whatever was on her mind. That perhaps made him repent so much. She remembers a rare outburst when she reacted strongly because her husband demanded sex on the $90^{\text {th }}$ day after her delivery. She rejected him and shouted, "I cannot be a wife whom you expect to share your bed with, but as a responsible wife I will support you and care for you till death as it's my duty". After this incident he never forced her ever after; she feels that may be because she asserted then and resisted all these that she was able to live longer. Her decision to shift to her own house turned her in-laws hostile. They accused her of stealing away their son. It was a sad reality that they did not know that it was their son who wanted to stay away from them, not wanting his family to witness his deterioration. Her parents thought her husband was suffering from psoriasis.

Her second delivery was very complicated. She went to a hospital just for delivery hiding her status. Baby was underweight and it was small. Looking at her baby and thinking about the baby's future life, she even had thoughts 
of killing the baby. Her tension and depression during pregnancy was very clearly evident in the baby.

\section{Death of Her Husband -widowhood -stigmatisation}

When her baby was eight months old, her husband turned very sick; he had severe chest infection and developed pneumonia. The next day he desperately wanted to go to the hospital, and she took him to prominent private hospital. By this time he was extremely weak and was breathless. The doctors moved him to emergency ward on arrival as his breathing was even more difficult. Agipa remembers that she had only planned to undergo a check-up and then get back. She too was not prepared, but had to call his house to inform about his critical condition. Although the doctors wanted to run more tests, he refused and pleaded holding her hand asking her to take him home before others knew that he was HIV infected. She went into a soliloquy: "I never thought that he will die...but I was sad and I sat in a corner and then I prayed to God to take care of him." She remember being adamant to take him to medical college for better treatment even when her uncle resisted. Her uncle instructed her to accompany a friend of his, who was to pick her up. When he came his friend ready to take her home, she resisted and was angry wanting to accompany her beloved to the Medical College. They forced her inside the car and forced her to listen. He shouted “...he is gone!" She remember reacting in shock and pulling his collar asking him whether he is joking". He answered in a more composed manner, "lady, you lived with him these days knowing about his condition... he is no more now ... we are preparing to bring his body home!". She wept uncontrollably sad and cried all the way from hospital to home.

She recalled talking to herself, "I felt as if my life had ended. I never believed him and hoped he might be lying. When I reached home, I saw every one waiting there and it was raining heavily. My mother saw me and started crying and I knew that it was for once true". Her elder daughter was 3 years and her younger one was 8 months old, then. "I was near the body the whole day". Everyone comforted her and asked her to stay bold and they advised her to move to the half built house as soon as possible. Her father was completely broken seeing all this. She commented that she had been married hardly five years then, and then by 27 , she was a widow. When they brought the body to his house, her mother-in-law blamed her for stealing her son for a year and bringing him dead. They abused her not knowing what really had happened for the past one year. They always said bad things about her even after my husband's death. Even her family started accusing her for not taking care of her husband and many times she have felt that she should reveal the status lest she started hating her life. On the $41^{\text {th }}$ day after her husband's death, everyone came to visit and she thought it was the right time to reveal what was a secret till then. She revealed to them about how he had died, and also her, as well as her elder daughter's status. Once this was told everyone left; not even her brother stayed back to comfort her. She comments; "All I had was my mother, father and two kids. This was my first turning point in my life; I decided that I should live my life to make a statement, to prove them at least. Even though I had quick thoughts about suicide I started thinking about my kids and I wanted to live for them."

She had to live in the half-complete house after her husband has passed away. She had a lot of problem in getting back her property from her in-laws; she stayed in this house with her kids alone and furnished it completely with her work and effort. Some of her neighbours noted superstitiously that it was inauspicious to wake up every day they and to open their door to see a widow. Instances like these have hurt her so much. She later changed her attitude and resolved to keep her mind away from all this and purposely tried to be positive for her own wellbeing. Many a time, she would come across her schoolmates, and when they knew that she was a widow, they expressed sympathy for her. This sympathy which she thought condescending, made her stay away from them. There were a few instances in which her friends knew that she was infected too and were shocked. "I try to avoid such situations mostly. It's difficult for them and me. So why create such a scene?" She remembers one touching event was that she had to coordinate and was booked to make a positive speaking section. The PRO contacted her over phone and on the venue she realized it was her close school friend who she had made appointments with and it was devastating for both of them.

She always tried to avoid close relationship especially with the opposite sex after her widowhood. Generally, if a man got close with her, she would make sure to clarify his intensions. She comments, "If he is approaching in a different way I sense it fast, and keep a distance. If there he puts too much of pressure I reveal my status... so then I'm safe." Being a widow, she thinks it necessary to take precautions. People try to approach for all the wrong reasons. There is a general tendency when someone sees her standard of living is improving, to talk ill about it, attributing wrong reasons for the affluence. In her case, she hears derogatory comments regarding her wearing good clothing or even a bindi. "People think after being a widow there is a stereotypical way one should behave...they expect you to cry all day and act as if there is no after this. If not they accuse you of celebrating widowhood and attribute you of being "loose"'.

She is cautious of her neighbours. If ever there was a visitor, or a car, or a bike, seen in front of her house, then people turn far more curious wanting to see who it was. She never gets invited to weddings. Even during the house warming function of her own house, she was not permitted to do the first entry as she was "a widow". Her relatives accepted her only recently only after they were convinced that would not be burden to them, and, also because she looked healthy. They were concerned that her infection does not spread to the rest of the family. When she started 
to live alone she had to struggle a lot. She did not have a regular job or income; forget even having Rs.10. Initially she had a lot of struggle hunting for jobs with no help from others. She took up flower arrangements where she started to work for just Rs.500. Later she quit her job because she used to bleed her finger every time with thorns from the roses; this was critical given her condition. She had to hide her status when she had to work there. She was very scared about any infection as she had a baby of just 8months old; she always used to think "what if they get infected because of me ?"

She eventually had to quit the job. That too became an issue as her relative who got the job, not quite understanding her special condition, blamed her for her attitude. After few days she received a call from ICTC from her counsellor and he introduced few other HIV infected patients and showed how they continued to live their lives positively, in spite of their struggles. After few days of acquainting with HIV-positive people, about 7 people including her registered TDNPP (Trivandrum District Network of Positive People), a charity organization. Later, at the State level, they had CPK PLUS and TDNPP worked along. This organisation worked for HIV positive patients (PLHIVs). As of the time of study the Agipa's NGO has under it more than 1000 registered HIV patients. She started working as a field worker and had to struggle a lot. There were hardly any people coming forth to tell their status as there was a lot of stigma. They started helping people who had similar situations. There was a project from Central Government and there she was promoted and worked as a project coordinator for four years.

\section{Present Scenario - Work, Heath, Emotion, and other Aspects of Life}

AIDS Controls Society later tapped her expertise and called on her to spread positive awareness. Her positive outlook and ebullience generated good response. She is convinced that hospitals and the health care professionals have lot more stigma than any other social institutions and the general public. She has had fairly good response in her field work. Initially aids control society had a wrong approach they tried to intervene by spread awareness in a way that generates more fear, stigma and rejection using the imagery of an Octopus. In contrast, her positive speech helped in creating awareness and that she never faced discrimination there. This exposure has gifted her with tremendous amount of satisfaction and meaning in her life. She could change a lot of negative attitude in people by her talk and experience sharing. According to her most of the people suffer from self-stigma than projected stigma. She yearns to have a partner in her life who would care and support her as she lost her husband very early in her life. She had been approached too by young suitors. She explains 'I'm sharing with you about this not to boast about another person's affection for me. Rather, I wish to highlight that I had options to live my life on my terms as I have nothing more to lose. But I took the difficult option to keep myself chaste and strong, and learning to say "no!" to certain things and people in life, no matter how much I missed it".

She is very aware of how much these situations have cost her life and so she is self-determined not to be a reason for any other life going awry. On other hand from her experience she realized that all people have a secret motivation for whatever they do it for us "nothings comes for free". Few times she has felt she needs someone who loves her and takes care of her but never want a remarriage. She shares, she is much better off at present. When stressed, it takes a toll on her health, and she withdraws into her own cocoon. So, in order to adapt, she purposefully avoid such situations and temptations and rather resolutely says; "I have not lived for me from my $6^{\text {th }}$ STD till date...I can claim rightfully more than anyone else that I have lived a selfless life." Yet, she remains deeply pained, having lost two very important men in her life, her husband and also her blood brother, whom she misses blind. Her peer group and friends have been a great support; the fact that they look up to her and perceive her more as a person in a position to help them creates a formal space limiting her to open up on deeper personal desires.

For her there is not much change in her belief in God. When she knew that she was HIV positive she had cursed herself and God. "I started strongly believing in him again my second child was identified negative". Everyone including herself, believed in the highest probability of the baby being born HIV positive. She even had breastfed her baby till a year and a half year. She recalls how each dilemma posed a great learning. She remembers that when her second daughter was about to be tested, she was contemplating of killing herself. Finding out that she was "negative" on HIV, status taught Agipa, a lesson, that planning in life is necessary, but not over-planning. Because, until about the time the result was revealed, all she was planning was how to kill herself and the kids. She confessed that she learned that life is to be live and not to be stupid. Another learning was not always believe what we think might be absolutely true. She is happy as she have been a reason to stop many people from attempting suicides and a motivation to people who had thought on similar lines.

For her to live positively means is not easy. It does not solely depend on a person but the support system they have created for themselves. For her the ideal situation is only when they the HIV positive widows can come forward accepting their status, much like 'coming out' among individuals who are gay. Ready to struggle and having an urge to move on, she also demands that the society accept the HIV-positive as a part of it like any others. "Don't we have drunkards, robbers, and anti-socials elements...and what are we doing to them? So why cannot people accept the innocent victims of this particular condition? It is not even contagious like the normal fever or flu, which can 
spread easily! Be with them in struggle, rather than isolating them".

She was positive to acknowledge that not all manifested stigma and discrimination towards her; this varied and cannot be generalized. She believes what women needed was an income; it permitted them to stand on their feet. If a woman had a steady income, half of the work and struggle is relieved for sure. She observed, "Dependency is a problem for women!" There are many widows, who actively participate in the income generations programs of Kerala State AIDS Control Society (KSACS); ornament making being one such activity. She shares on how, many women who engaged in work of their interest, remain in a 'different world' and managed to forget their woes. People say they have improved on their creativity, concentration, and patience. Once, when a training program was organised at the Prathyasha Clinic, the District Panchayath President, who inaugurated the program, on being sensitized about their situation, asked for statistics at the Panchayath-level; she requested Agipa to draft up an appropriate project for self-employment generation as funds were readily available. She believes that such initiatives would ensure in better living conditions. Her close association with HIV positive women working in this field convinced her that that $90 \%$ of the women are innocent victims infected by their husbands, who died soon after.

Agipa dared herself by not taking medicine although her count is much below the WHO prescribed standards. She was quite well informed and also educated the researcher about the combinations of three medicines (cocktail) and told she is having a problem with her HB count. She prefers to stay away from ARTs as long as possible, as these were very strong medicines which ought to continued life-long; moreover she thought that its reaction and side effects have never been studied, are not predicated and usually vary from person to person. The ART combination "Staudin" suggested to her, had serious side effects which she believed would have a serious an impact on physical appearance if administered. This combination, according to her, acted in a manner to removed fat from certain designated zones of the body. For her it was a priority to possess a 'good body' and health till the end of my life. She shared, "I don't want others to question me when they witness a sudden change in my physical appearance." Moreover, she could not afford to stay away from work and responsibilities during the initial test dose period of 15 days. She adds, "I'm personally not against the medicine, and I'm not scared but I lack the support system to try this. And, if anything happens to me, neither do I have money to be spend on that, nor do I have people to look after me. My life goes very systematically; if there is any change here or there, it will go for a toss and it will be difficult to manage and get back to normal".

According to her, the organisations engaged in intervention and rehabilitation among the HIV Positives promote ART only with the object of achieving targets without considering the family or person affected; neither was it concerned of how the patient manage it. These seem to be the major drawback in the treatment strategy. Further, ARTs acted on each individual differently and the outcomes could never be generalized. She followed a definite routine. All though she does not spend so much money on food, whatever she had was healthy enough to help her maintain her immunity level. Her exercise was limited to engaging in household works such as sweeping, mopping the floor and a regular one hour walk to and from her office. She is highly conscious in kitchen and takes precautions; for instance, if she cuts herself she discards the entire portion of food; during the time of her periods she uses a different toilet though. She keeps away from her kids during any infections or cuts.

Responding on a question regarding the support system vide various organisations, she commends Pratyasha for the invaluable support; the only problem encountered was the reluctance of people in coming forward on account of stigma. This limited their access to services they could have benefitted from. SACS has improved its operations after hiring a GIPA Co-coordinator (Greater Involvement of People Living with HIV/AIDS). When more people who were HIV-positive were coordinated, their needs would be voiced stronger. Regarding taking the aid of counsellors, she claims to be in constant touch with her first counsellor, with whom she used to share everything; the counsellor was her greatest friend and advisor until recently. There seemed to arise some court cases regarding some controversies within the SACS, and she being part of SACS, her role was suspected in certain matters that affected them. In spite of her repeated attempts to meet the counsellor, she could not break the ice, which was in effect a big blow to her considering that she had no place to go and ventilate.

She was healthy in general, and had minor skin infections for which she underwent Homeopathy treatment. She was generally a very short tempered person and she used to throw objects especially after her husband's tragic demise. She also used to get violent with her children. Yoga and meditation, helped her in substantially reducing her stress and anger. She changed this behavior when she realized herself that this attitude is not helping. Moreover, she was regular to the temple and that gave her a lot of peace. Listening to music was another diversion. She shares her problems and financial constraints with her children so that they also learn the art of living. She had not till the time of the interview disclosed to her children regarding her HIV status although she told them that she worked among the HIV/AIDS patients. The researcher noted her to be an emotionally balanced person while dealing with the children; she was neither not anxious nor monitored them frequently. On the other hand, she trusted them and advised them to do what they liked. However, she warned them about her limitations and told them not to let her down. She was very systematic and would become distressed if ever she violated a routine. She provided everything with her means and vowed not to pamper nor spoil them. She also shared her problems and financial constraints with her 
children. Her elder daughter was very sensitive and held very high opinion about her father and she is worried how her daughter will react when she learnt about his death and Agipa's status. She was working out a strategy with the counsellor on how to deal with this situation of divulging her status. She also shared her anxiety about getting her daughters married and wondered how the groom would view the realities in order to avoid future problems. She has few liabilities on her house construction. She have friends who have helped her through her tough times mostly financially, she believes many a times God has been kind to her.

Her greatest achievement she believes is her attempts at building her own house. She quipped that the house the researcher saw was not the present structure, but was once in pure shambles. So rebuilding on the same was like "Phoenix rising". She takes pride in mentioning how she worked hard and raise resources in converting the "kuratheerathaveedu" (a wall-less, bare structure once a landmark for the people), into a complete, live-able house she lived in. Her children and parents completed the picture, transforming the 'house' into a home. Although she incurred liabilities on this account, she had no regrets, and took pride in it. Her parents turned very supportive after her husband's death, and helped her maintain her house neat and tidy. She insists with her kids to maintain her small house the same way she did, after her death. Her younger daughter, who happens to be grade five in school, helps her a lot. All her little savings go into buying things at her home. Her first purchase was a small TV stand, which doubles as a shelf for her children's trophies. Her children often mocked her commenting, "Amma, you're not watching the TV program, but you are actually admiring the stand." Her next dream project is a sofa, which her younger child had been wanting for a long time. She then remarked, "These may be minor things in others' lives, but for me these make life meaningful.". The researcher realised how much these 'little things' mattered in salvaging lives of the affected, transforming them, resurrecting them. In short, the researchers are all the more convinced that Agipa, is a Pheonix rising from the ashes that once consumed her.

\section{Future Plans}

About her future plans she aspires to complete her Post-graduation. She planned to do a course in Social Work (MSW); this was more of a felt need when she realised her lack of competency and demand for a professional touch in the field of operations. Her crowning moment on completing MSW was expressed, "Yes! ...I have defeated my virus." The researcher argues that this perhaps might be an understatement; the words "I have defeated" and "defeated My virus" belies the control she was able to exert on fate, that seemingly would have dashed the hopes of an average woman. And Agipa is no average woman; she is a Phoenix bird rising and journeying towards to horizon.
Having completed MSW, she now aspires to do an M.Phil., ending up in an integrated $\mathrm{Ph}$.D. At work, she remains very self-motivated and took upon her the challenge to write comprehensive reports, something that usually a professional social worker is expected of. She feels that as an HIV infected person, whose life was "deadlined", it was her responsibility to create a healthy and better life. She yearns to see her children settled in life. She plans to buy a plot of land measuring about an are and a half for her younger child, as she had no major savings. She had locked away whatever little money her husband had saved, into a fixed deposit in the name of both her children.

Her journey towards the horizon starts with her advocacy for women. She desires to remain and contribute in the area of individuals, especially children, affected by HIV/AIDS. Even though HIV has been much discussed and various steps initiated to handle stigma, HIV afflicted women and widows are not in a position to 'come out' and divulge their status. If the government provide a way of income and support for HIV infected widows, then their standard of living of so many of HIV patients would improve. Agipa was keen to showcase attempts at this especially self-help groups that engage in handicrafts such as Pearl-, lotion- , soap-, and candle-making, etc. Such enterprises helped widows affected and afflicted by HIV to think positive and remain creative throughout their crises; especially important was the emotional support the coming together brought. She observed that many of HIV affected widows will come out of the shadows, if Government helps them find employment. She was happy to speak on behalf of the HIV-positive, although people have advised her to stop it as her kids are growing. Her 'last wish' so said, is to die talking about HIV-positives. She vows to advocate for the HIV-positive no matter how much her life changes. She feels a strong urge to bring change to other people's life by any means of influence. She has gone beyond addressing problems of widows to engage in session on safety in hospital settings; one of her advocacies is about insisting with hospital staff to take the precaution of wearing gloves a common practice, as any person who comes to take donate or take a blood-test might have some disease. Her point is why discriminate against the HIV positive alone? This would automatically stop stigma and discrimination against the HIV positive. She is also advocating for divulging HIV status so that it becomes an automatic response therefore a step towards fighting discrimination. Agipa also shared her experience with a nurse who refused to use gloves even when she insisted, but on being told that she was HIV-positive overreacted by wearing two gloves. She sometimes feels monotonous and a lot pained by her situation and responsibilities and pressure of family and work. But the cause is always her motivation .to her no matter how much ever she says the feeling had not died down in her and is fresh and still she gets emotional. The feeling that she went through can never be expressed fully no matter how much ever she says. 
The researcher found it a great learning to realise that in life, we it was not the big things that built happiness, but "little things" that mattered. And, it was how we perceived life that matters rather than having everything. She acknowledges the immense support of her parents. Even at her prime age, her mother cares for her more than anything. She voices her anxiety stating, "Definitely there are a lot of tension and stress in my life, more because I'm alone and I'm the pillar of my family. And if ever something happened to me, that moment everything ends. It's like I'm walking a thin thread. But we have to keep looking at the bigger and better picture,... to move on." There is both serenity and a strong response when she says this that punctuates her determination.

\section{Findings}

One of the major aspects of the study on widowed PLHIVs was to ascertain their quality of life. Quality of life pervades various six key life domains - physical, emotional, spiritual, psychological, sexual, occupational, social and economic. Some of the realisations along this line included certain facts:

- $\quad$ Physical - a plunge in the CD4 count did not always entail administering ART medications; unlike commonly perceived, it was impossible to judge the HIV positive by physical appearance (two of the cases appeared in their pink while the third appeared a little emanciated; adequate precautions being taken to avoid infections, with proper hygiene, rest and good diet, the immune system could be boosted substantially to entitle the HIV positive have a long healthy life even without medication (all the cases discussed had survived without overt symptoms for more than ten years, an in once case almost over 15 years. All the three were conscious of their health and would seek medical support at the slightest sign of ill health.

- Emotional: Financial burden was a major additional stress the had adverse effect on the persons health mental and physical; the challenging childhood experiences (as reported in two cases) has resulted in better resilience and adaptability to the life crisis of being discovered HIV positive; peer support or the availability of an empathetic person to understand was a great relief and a strong adaptive mechanism to reduce stress; the extended grief cycle and DABDA grief process (Ross, 1969) were observed but on varying degree and patterns of occurrence; many of them eventually came to the point of forgiveness given the fact that their husbands did the unpardonable of infecting them; all of the incumbents had to fend off men who made advances at them, some in spite of being told of their status persisted

- Spiritual: the researcher found that they were not resentful of their fate nor cursed the "Gods"; there ended spirituality as they were highly religious.

- Occupational: none of them willfully disclosed their status to their employers; it is startling observation to find discriminative practice to be coming from the more educated, e.g. doctors, nurses, officials, etc. One among the interviewees officiated as an animator in initiating general programs for the public; she vouched that she was blessed with immense care and support from her colleague who were well aware of her status of being HIV positive. This opens up the possibility of incorporating more HIV positive into the NACO and KSAC hierarchy as they delivered services more empathetically.

- Economic; all three cases are the primary bread winners of their respective families being bereft of their spouses. They did suffer great hardships by managed their liabilities systematically. Being transparent in their approach to parenting, the children of PLHIV widows too were aware of their hardships and were more adjusted in understanding and managing things on the domestic front

- Sexual: the casualness with which men approach them for sexual contact had inculcated in them a strong aversion towards sexual contact; for this very reason they avoided close relationships with the men; for that matter they exhibited little or 'no sexual appetite', and may be regarded as frigid.

An analysis of the coping strategies adopted by the PLHIV widows indicated the following; there is more of 'self-stigma' especially in the initial stages, than perceived stigma. Their approach in handling self-stigma or discrimination was to practice avoidance; such an approached proved more rewarding as they realise the futility of changing other's attitude. Self-indulgence, by way of engaging themselves in what they like was found to be the best coping strategy. Given this the researcher understands the possibility of incorporating cognitive behavioural therapy (CBT) as a means of bringing about cognitive restructuring.

The third objective attempted to understand and analyse the various social support systems that moderated their adjustment. It was quite a startling revelation to find that stigma and discrimination by society cannot be generalized; it varied with age, gender, culture, education, etc. PLHIVs who were widows suffered terribly because of the total absence of support from the in-laws. They were left only with their aging biological parents; not even their siblings were willing to provide support - instrumental or expressed. This was compounded by the adverse behaviour, stigmatization and discrimination from people in the community. 


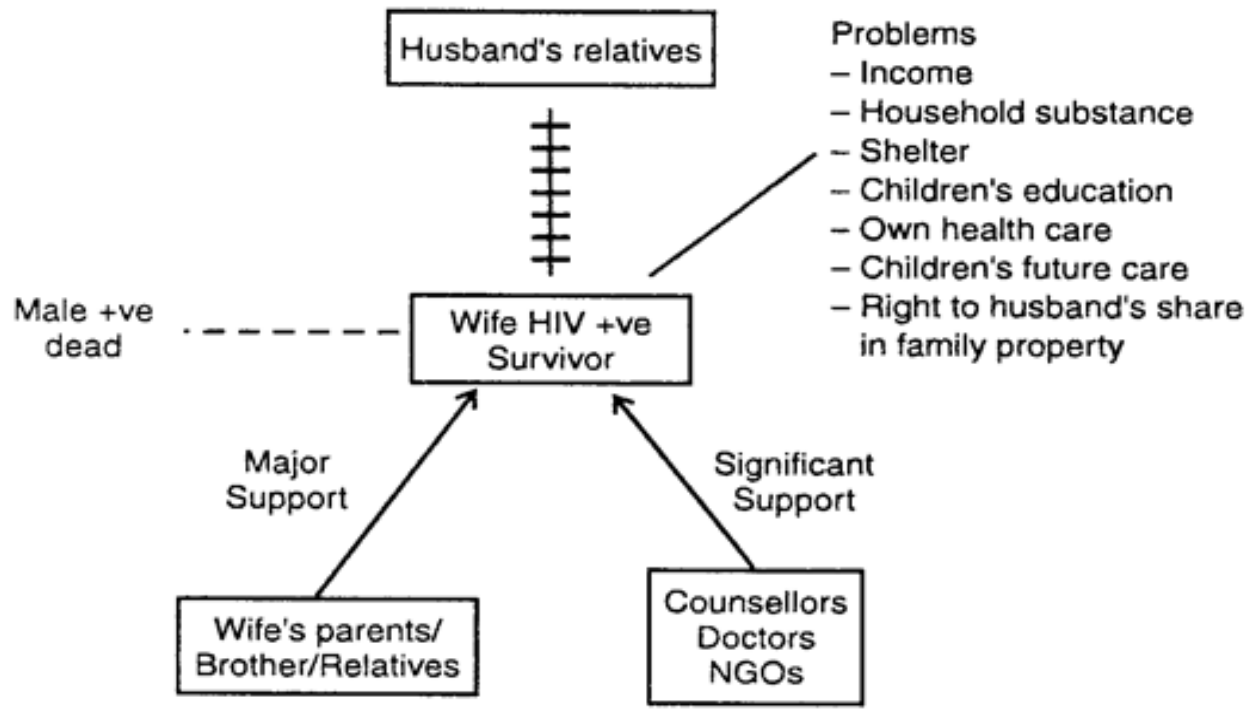

HOUSEHOLD RESPONSE TO WOMEN WITH HIVIAIDS

It was finally their 'own' family in all the cases that provided the support - instrumental and expressive. Although socially active, all respondents did experience inhibition in meeting new people as they found it discomforting to interact and reveal their details, leave along their status of being "HIV positive". Even meeting old friends and acquaintances was a difficult proposition given their fear of being labeled as "the HIV positive". They were extremely anxious of the possibility of their children's discovering their 'HIV positive' status. In other words, their adjustment and confidence post-infection was contingent on how their limited and receding social systems would accommodate them. Social institutions that mattered, especially hospitals discriminated heavily; private hospitals show it explicitly being reluctant to admit them on fear of damaging their reputation. This criminal discrimination happened especially when they had to get medical attention during emergencies such as delivery or an accident, and even in general situations such as pregnancy, treatment for TB and Pneumonia which were co-morbid manifestations. Their job satisfaction was higher when working in NGOs or work that involved dealing HIV afflicted. As time progressed they find that the government and the NGOs are eventually 'deserting' them; there is hardly any special scheme supporting widows, who are PLHIVs by National Aids Control Organization (NACO) or any State Government. The State's involvement is limited to a meager provision of Rs. 400 as monthly pension of to all HIV infected. The only solace are the existing Voluntary Counseling and Testing Centers (VCTCs), which assist in testing individual to ascertain their status and the Drop-in Centers that provide ARTS and necessary medicines for HIV positives. But the PLHIVs especially widows are fighting a losing battle with the government slowly disengaging from this scene.

\section{Conclusions}

It is a matter of shock to realise that almost more than half of those adults living with HIV and AIDS, are women. The AIDS epidemic has had a unique impact on women, which has been exacerbated given their passive role within developing societies and their biological vulnerability to HIV infection. Women, especially those in developing countries suffer a triple jeopardy - being a woman, an HIV positive and yes, being a widow. The first qualifies and demands that a woman be passive in a male dominated world; the second puts her health in danger given the fact that she has a biological vulnerability, less access to food, hygiene and health care; the last renders her devoid of any social support from the side of the in-laws of the deceased husband, putting her at the absolute mercy of her own aging parents with her sibling turning the Nelson's eye to her misery. Hence, there is no doubt that widows who are PLHIVs may be treated in a manner that socially, culturally and economically disadvantage them.

A look at the life experiences in three cases shared brings some silver-lining in the cloud. This has got a lot of implications for social work. For a first, it explodes the myth that they will look emaciated. Social work needs to design specific interventions that would highlight the possibilities of living a normal life thereby giving hope of living a more complete and meaningful life. This would also help in reducing the stigma attached to HIV/AIDS that was once considered a doomsday scenario. We need to help the public realise, that with necessary precautions, adequate diet, 
reasonable exercise and rest, the HIV positive are able to live an extended life with much better quality. But all of this depends on their resilience gathered resisting the storms during the early years of life. Secondly, social work especially the basic methods whether it be social casework, group work or community organization, all depend on mobilizing resources - internal and external. The most important among these, and what determines the extent of recovery, happen to be the quantum of social support the individual, group or communities gather. A good many of the widows affected and afflicted by HIV/AIDS, fall back on their families of biological origin, to continue the fight with their fate. Their resolve to live comes from the strong realization that they have a reason to live - their dependent children and aging parents - the only ones left. This is an uphill task in a state like Kerala where the density of population is high, and given the high tele-density. The news of HIV/AIDS invokes stigma and very strong discriminatory practices that need to be abhorred. The greatest fight will be and will have to be stigma, more importantly self-stigma. In all the three cases explored, these women having made meaning of their fate, and pardoned the unpardonable mistakes by those men who swore before God and man to be their partners for life. In this manner, these noble widows epitomize the Phoenix, rising from the ashes. The greatest learning for the researcher is the realisation of the innate resilience that human beings garner in a crisis. There is an inner source of strength in everyone, more specially with women and men, who emerge from dire circumstances and crisis. Their challenging experiences instill in them a "never-say-die" attitude. Being with Agipa humbled the researchers. For, one cannot underestimate nor ignore the immense resolve and determination with which these noble, innocent widows salvage their lives. And truly in that manner, they are Phoenixes, winging and heading towards the mighty blue skies beyond the tranquil horizon.

\section{REFERENCES}

Dr. Reeta Sonawat (1999) - HIV/AIDS: Coping Strategies

Dr. Digumarti Bhaskara Rao (2000) - AIDS \& Home care

Dr. Jose Therempillil, CMF (2006) - Socio-cultural dimensions of the HIV/AIDS affected.

Division for the Advancement of Women/DESA, United Nations-(December 2001), Women 2000.

Vuyiswa Mathambo, Andy Gibbs - 31st August 2008 -Qualitative Accounts of Family and Household Changes in Response to the Effects of HIV and AIDS: A Review with Pointers to Action.
UNAIDS.(2007). AIDS Epidemic Update - 2007. Geneva: UNAIDS.

UNICEF. (2008). Children and AIDS: Second stocktaking report. New York: UNICEF

Maria de Bryun- 5th October 2005 Women, gender and HIV/AIDS Where are we now \& where are we going?URL :http://www.heart-intl.net/HEART/011507/WomenGe nder\&HIV.pdf

UNAIDS. September 1998. Gender and HIV/AIDS.Technical update. Geneva UNAIDS

URL :http://www.unaids.org/NetTools/Misc/DocInfo.aspx?href=h ttp://gva-docowl/WEBcontent/Documents/pub/GCWA/JC986-Epi Extract_en.pdf

Warwick, L., Bharat, S., Castro, R., García, R., Leshabari, M., Singhanetra-Renard, A. \&Aggleton, P. (1998).Household and community responses to HIV and AIDS in developing countries. Critical Public Health, 8 (4): 311-328

Krishna, V., Bhatti, R., Chandra, P. \&Juvva, S. (2005). Unheard voices: Experiences of families living with HIV/AIDS in India. Contemporary Family Therapy, 27 (2): 483-506.

Belsey, M. (2005). AIDS and the family: Policy options for a crisis in family capital. New York: United Nations

Bharat, S. \&Aggleton, P. (1999).Facing the challenge: Household responses to HIV/AIDS in Mumbai, India. AIDS Care, 11 (1): $31-44$.

Bor, R. \&Elford, J. (1994).The family and HIV. London: Cassell

Castro, E., Orozco, E., Aggleton, P., Eroza, E. \& Hernandez, J. (1998).Family responses to HIV/AIDS in Mexico. Social Science \& Medicine, 47 (10): 1473-1484.

Nkurunziza, E. \&Rakodi, C. (2005). Urban families under pressure: Conceptual and methodological issues in the study of poverty, HIV/AIDS and livelihood strategies. Urban household livelihoods and HIV/AIDS - Working Paper No. 1, University of Birmingham, International Development Department.

Songwathana, P. (2001). Women and AIDS caregiving: Women's work? Health care Women International, 22: 263-279

Cross, C. (2001). "Sinking deeper down" HIV/AIDS as an economic shock to rural households. Society in Transition, 32(1): 133-147.

D'Cruz, P. (2002). Engulfing darkness: the impact of HIV/AIDS on the family. Families in Society, 83 (4): 416-430.

Deininger, K., Crommelynck, A. \&Kempaka, G. (2005). Impact of AIDS on family composition, welfare, and investment: Evidence from Uganda. Review of Development Economics, 9 (3): 303-324.

Hyde, J. (1993). Changing concepts of the family: Responses to HIV/AIDS and development. Journal of Society for International Development, 4: 22-24.

WHO/UNAIDS. December 2004. Women and AIDS. An extract from the AIDS epidemic update December 2004. Geneva, WHO/UNAIDS. 